\title{
Analysis of Student's Mathematical Reflective Thinking Ability in Number Pattern
}

\author{
F Apendi ${ }^{1}$, S Prabawanto ${ }^{2}$ \\ \{fitriani14@upi.edu'1, sufyani@upi.edu² \\ Universitas Pendidikan Indonesia, Indonesia 401541 1,2
}

\begin{abstract}
The ability of mathematical reflective thinking must be possessed by students in Industry 4.0. This study used descriptive qualitative research that aims to determine the reflective thinking ability of senior high school students on pattern numbers. The research subjects were 10 students of class XI. Based on data analysis, it is found that: generally students could (a) check the validity of arguments based on the concepts used, (b) identify mathematical concepts used in mathematical solutions accompanied by reasons, and (c) show the difference between relevant data and irrelevant data in solving problems. Whereas only a few students can (a) generalize accompanied by reasoning, and (b) solve problems using various completion strategies.
\end{abstract}

Keywords: Mathematical Reflective Thinking, Patterns of Numbers

\section{Introduction}

Reflective thinking ability was first proposed by John Dewey in 1910 in his book How We Think Dewey stated that reflective thinking is a careful and deep thought process for thinking about what is known, what must be known, and how to bridge this gap [1]. This means reflective thinking has a role in problem-solving that involves critical and creative thinking [1]. In line with the opinion, Sabandar (2009) stated that reflective thinking skills in mathematics that contain critical thinking and creative thinking skills as well as other thinking abilities will give students an opportunity to develop problem-solving abilities [2]. Taggart \& Wilson said that in solving problems, decision making is needed, reflective thinking is the process of making informed and logical decisions on educational matters, then assessing the consequences of those decisions [3].

The ability of reflective thinking can be seen from how to respond to problems, explain the processes, correct errors found during problem solving, and communicate ideas [4]. In detail, reflective thinking is self-regulation to generate interpretation until conclusion. Someone who used reflective thinking ability will has ability to identify the problem, choose alternative of solution or solution strategy to generate an interpretation, analyze problem and evaluate solution, conclude and decide the best solution to problems given [5]. The ability of reflective thinking can support students to choose, sort, and consider the decisions that are taken to be mature and responsible. Reflective thinking ability can be obtained by students through a process that requires them to practice continuously in reflective making decisions [6].

Dewey was divided reflective thinking into five stages, namely (a) propositions (thinking or considering possible solutions), (b) intellectualization (analyzing problems in depth to solve them), (c) using one proposition (focus one strong opinions to start problem solving), (d) mental 
elaboration (correctly assuming the idea and reason for one of its parts), and (e) testing a hypothesis (implementing a hypothesis made in a real situation) [1]. In this study, indicators of mathematical reflective thinking ability which are measured were: (1) check the validity of arguments based on the concepts used, (2) identify mathematical concepts used in mathematical solutions by reasons, (3) show the difference between relevant and irrelevant data in solving problems, (4) generalize by reasoning, and (5) solve problems using various strategies.

A study shows that reflective thinking is not attention yet in mathematics class. The teacher gives formulas, the problems example and their solution, and then the exercises. This activity often occurs in several schools so that students' reflective thinking skills are less trained. This fact implies that students' mathematical reflective thinking is still low, as Nindiasari research report in a Senior High School in Tangerang, Banten [7]. This report shows that the teacher gives formula in explaining a mathematical concept and almost $60 \%$ of students can not achieve mathematical reflective thinking. In addition, in line with Salido and Dasari report that students' reflective thinking skills in high school have not been developed optimally. It is also reported that students with a high level are at the reflection stage, students with a moderate level are at the understanding stage, and students with a low level are at the habitual action stage [8].

One of the mathematics topics learned by students in school is number patterns. This topic is very close to daily life problems, often on National Examination, College Entrance Examination, and prospective employee examination.

\section{Methods}

This research was descriptive qualitative. The research subjects were 10 students of grade XI of a Senior High School in Jatinangor, West Java. The test used was a test of mathematical reflective thinking ability on the number pattern topic that consists of 5 tasks. The data analyzed was students' test results combined with interview results.

\section{Results and Discussion}

Based on the analysis of students' mathematical reflective thinking abilities, generally, students check the validity of arguments based on the concepts used, identify mathematical concepts used in mathematical solutions by reasons, show the difference between relevant and irrelevant data in solving the problems. whereas only a few students can generalize by reasoning, and solve the problems using various strategies. The highest reflective mathematics thinking occurs in the third indicator which is to reach $83,75 \%$, whereas the lowest occur in the fifth indicator, which is to reach $11,67 \%$. Based on students' score it can be shown in Table 2. The facts show in Table 1. 
Table 1. Percentage of students' mathematical reflective thinking ability.

\begin{tabular}{|c|c|c|c|c|}
\hline \multirow[b]{2}{*}{ No } & \multirow{2}{*}{$\begin{array}{c}\text { Mathematical Reflective Thinking Ability } \\
\text { Indicators }\end{array}$} & \multicolumn{3}{|c|}{ Analysis } \\
\hline & & $\begin{array}{l}\text { score } \\
\max \end{array}$ & average & percentage \\
\hline 1 & $\begin{array}{l}\text { check the validity of arguments based on the concepts } \\
\text { used }\end{array}$ & 4 & 3,3 & $82,5 \%$ \\
\hline 2 & $\begin{array}{l}\text { identify mathematical concepts used in mathematical } \\
\text { solutions by reasons }\end{array}$ & 8 & 6 & $75 \%$ \\
\hline 3 & $\begin{array}{l}\text { show the difference between relevant and irrelevant } \\
\text { data in solving the problems }\end{array}$ & 8 & 6,7 & $83,75 \%$ \\
\hline 4 & generalize by reasoning & 10 & 5,7 & $57 \%$ \\
\hline 5 & solve the problems using various strategies & 12 & 1,4 & $11,67 \%$ \\
\hline
\end{tabular}

Based on students' score it can be shown in Figure 2. The first indicator, 8 students get score 4, 1 student get score 1, and 1 student does not answer the problem. For the second indicator, 3 students get score 8,1 student get score 7, 3 students get score 6, 2 students get score 4, and 1 student get score 3. For the third indicator, 5 students get score 8,1 student get score 7, and 4 students get score 5. For the fourth indicator, 2 students get score 10, 2 students get score 8, 1 student get score 7,1 student get score 6, 1 student get score 5, 1 student get score 4, and 3 students get score 3 . The last indicator, 1 student get score 4, 1 student get score 3,3 students get score 2, 1 student get score 1 , and 4 students do not answer the problem.

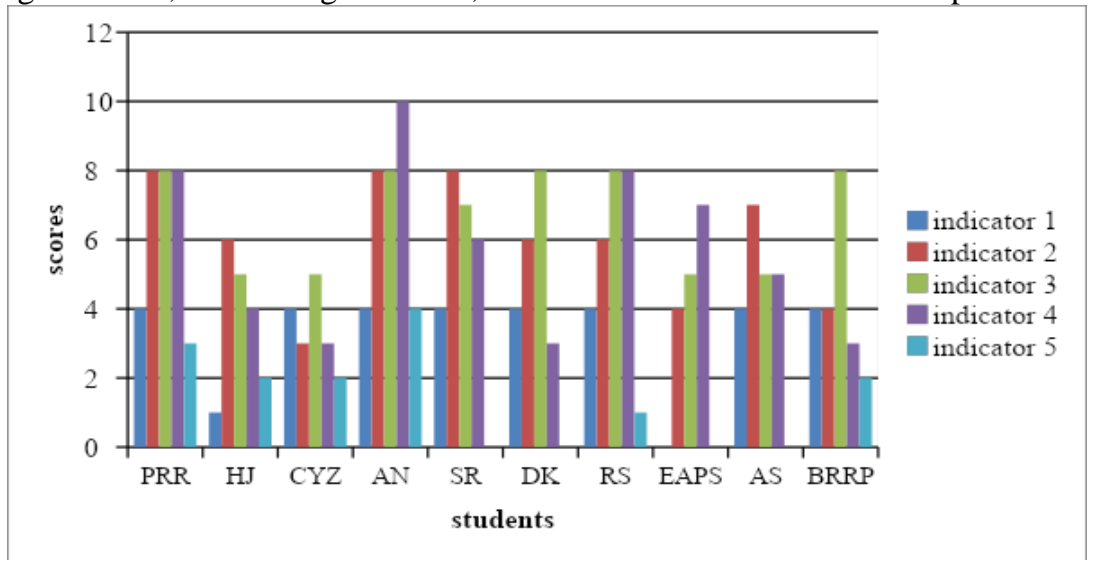

Fig. 1. Score of students each indicator.

A problem and the student answer that get the lowest score in the second indicator can be shown in Figure 2. Based on Figure 2, she doesn't know the information about the problem. It implication the concept used to solve the problem was wrong, and she doesn't validate the answer. 
Questions: The performance committee is arranging the seating of the audience. Seats are arranged in several rows. Each row is at odds between 4 chairs and the previous row. The first row contains 20 seats and a total of 24 rows. After the committee did the calculation, the committee found all 1224 seats.

What mathematical concepts did you use to check the committee's answers? Why did you use the concept? Explain!

If the committee answers wrong, try to write down the answers that should be explanation of the concept or formula used!

Answer:

Fig. 2. Test result of CYZ on indicator 2.

Analysis of the third indicator obtained data that almost all students answered the problem correctly. A problem and the student answer that get higher scores in the third indicator can be shown in Figure 3.

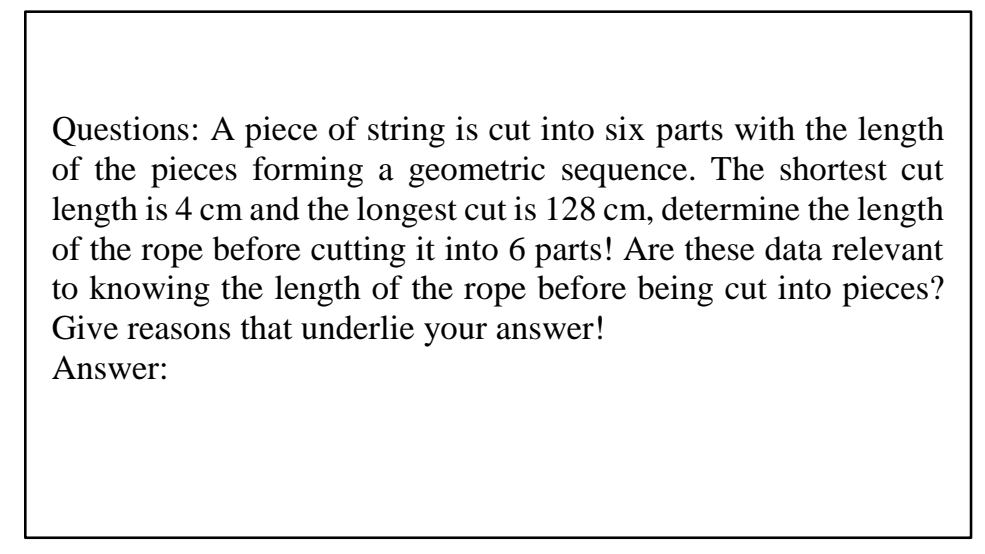

Fig. 3. Test result of PRR on indicator 3.

Based on Figure 3, He can explain that the data provided is relevant to find out the length of the rope before being cut into pieces. He illustrates and calculates data using the concept of geometrical series, so he can deduce the problem given precisely.

The description problem used to represent the fourth indicator can be shown in Figure 4. He wrong in understanding the problem. He wrote that part (a) required to find the $S_{n}$ formula, but that in part (a) it had to look for the formula $U_{n}$. Likewise in part (b) which should look for 
the $S_{n}$ formula. Because he could not understand the problem given, he was mistaken in the calculation process.

Questions: An arithmetic series with a difference of 3 has the number $n$ of the first term pertama . Task: Write down several ways to find the nth term formula. Then choose a method and finished!

Answer:

Fig. 4. Test result of DK on indicator 4.

Analysis of the fifth indicator was obtained that students could not answer the problem. Figure 5 showed the highest score which only reaches 4 points from 12 points.

Questions:The sum of the first five terms and the ratio of a geometrical series are 93 and 2.

$\begin{array}{ll}\text { (a) The geometrical series Un formula! } & \text { (b) The geometrical }\end{array}$ series $S n$ formula!

Answer:

Fig. 5. Test result of AN on indicator 5 .

Based on Figure 5, he doesn't write a variety of ways that can be used to find the $U_{n}$ formula. he thinks that $U_{n}$ is equation (1). He set 3 as a scale value $(a)$. One way to find the value of a by substituting the equation (2) into equation (3)

$$
\begin{array}{r}
U_{n}=3 n-17 \\
S_{n}=\frac{n}{2}(2 a+[n-1] b) \\
S_{n}=\frac{n}{2}(3 n-17)
\end{array}
$$

Based on the analysis of test results, only a few students have mathematical reflective thinking abilities. Some students don't understand the mathematical reflective thinking ability test given. The main factor influencing this is that students aren't trained enough to solve problems related to certain mathematical abilities, one of which is mathematical reflective thinking abilities. The main factor influencing this is in learning activities, reflective thinking is still rare and still difficult to be introduced [9]. Where one's capacity in reflective thinking is influenced by a stimulus-rich environment [10]. So, a stimulus to develop the mathematical reflective thinking ability should start to be optimized and expanded, 


\section{Conclusion}

Based on the results and discussion in this study, the mathematical reflective thinking ability of students senior high school in answering questions has not developed optimally. Description of the student's mathematical reflective thinking ability can be seen in the percentage of each indicator. Namely, generally, students could check the validity of arguments based on the concepts used $(82,5 \%)$, can identify mathematical concepts used in mathematical solutions accompanied by reasons $(75 \%)$, can show the difference between relevant data and irrelevant data in solving problems $(83,75 \%)$. Whereas only a few students can generalize accompanied by reasoning $(57 \%)$, and solve problems using various completion strategies $(11,67 \%)$. Therefore, students must be trained to think using HOTS questions in order to optimize their mathematical thinking abilities.

\section{References}

[1] Demirel, M., Derman, I., and Kragedik, E.: A Study on the relationship between reflective thinking skills toward problem solving and attitudes towards mathematics. Procedia-Social and Behavior Sciences. pp. 2086-2096 (2015)

[2] Dewey, J.: How we think: A restatement of the relation of reflective thinking to the educative process. D. C. Health and Company, US (1933)

[3] Subali, E.: Reflective mental attitude and cognitive ability: A study of reflective thinking skills in solving mathematical physics problems. International Conference on Educational Research and Inovation, Indonesia (2015)

[4] Nindiasari, H.: Reflective thinking mathematical ability. Papers for Individual Studies Task, Indonesia: Unpublished (2010)

[5] Nuriadin, I., Kusumah, Sabandar, J.J., and Dahlan, J.A.: Enhancing of students mathematical reflective thinking ability through knowledge sharing learning strategy in senior high school. International Journal of Education and Research, Vol. 3, No. 9, pp. 255-268 (2015)

[6] Sabandar, J.: Berpikir reflektif. [Online]. Tersedia : http:// math.sps.upi.edu/?p=55 [12 Agustus 2019] (2009)

[7] Skemp, R.R.: The Psychology of Learning Mathematics. Penguin Books (1993)

[8] Salido, A., and Dasari, D.: The analysis of students reflective thinking ability viewed by students mathematical ability at senior high school. Journal of Physics, Vol. 1157, No. 2, pp. 1-6 (2018)

[9] Mason, J.: Researching your own practice: The discipline of noticing. Routledge Falmer (2002)

[10] Papalia, D. E., and Feldman, R. D.: Menyelami Perkembangan Manusia. Salemba Humanika, Indonesia (2014) 